\title{
Penentuan Nilai Sun Protection Factor Aktivitas Tabir Surya Ekstrak Etil Asetat Daun Miana (Coleus atropurpureus) Secara In Vitro
}

\author{
Rosniah, Rolan Rusli, Aditya Fridayanti \\ ${ }^{1}$ Laboratorium Penelitian dan Pengembangan FARMAKA TROPIS \\ Fakultas Farmasi Universitas Mulawarman, Samarinda, Kalimantan Timur \\ Email: niia.niiansha@gmail.com
}

\begin{abstract}
ABSTRAK
Miana merupakan salah satu tanaman yang diduga memiliki aktivitas sebagai tabir surya. Penelitian ini bertujuan untuk mengetahui aktivitas tabir surya dari daun miana berdasarkan nilai Sun Protection Factor (SPF) dari ekstrak etil asetat daun miana. Penelitian ini menggunakan sampel daun miana dan diekstraksi menggunakan pelarut etil asetat dengan metode maserasi bertingkat. Nilai SPF ditentukan dengan mengukur absorbansi ekstrak dengan konsentrasi 75 ppm, 125 ppm, dan 250 ppm menggunakan spektrofotometer UV-Vis pada panjang gelombang sinar UV-B yaitu 290-320 nm dan dihitung berdasarkan persamaan Mansur. Hasil menunjukkan bahwa nilai SPF ekstrak etil asetat berturut-turut untuk konsentrasi 75 ppm, 125 ppm, 250 ppm sebesar 4, 7, dan 14 . Ekstrak etil asetat memiliki aktivitas sebagai tabir surya dengan kemampuan minimal, ekstra dan maksimal.
\end{abstract}

Kata kunci: Daun Miana, SPF, tabir surya

\begin{abstract}
Miana is one plant that is thought to have activity as a sunscreen. This study aim was to determine the activity of the leaf miana sunscreen based on the value of the Sun Protection Factor (SPF) of ethyl acetate extract of the leaves miana. This study used a sample of leaves miana extracted using ethyl acetate solvent by multistage maceration method. SPF value was determined by measuring the absorbance of the extract with concentration of 75 ppm, $125 \mathrm{ppm}$ and $250 \mathrm{ppm}$ using a UV-Vis spectrophotometer at a wavelength of UV-B (290-320 nm) and it was calculated based on the equation of Mansur. The results showed that SPF value of ethyl acetate extract was 4, 7, and 12 for concentration 75 ppm, 125 ppm, 250 ppm respectively. Ethyl acetate extract have an activity as a sunscreen with a minimum, extras and maximum capability.
\end{abstract}

Keywords: Miana leaves, SPF, sunscreen

\section{PENDAHULUAN}

Efek merugikan yang dapat ditimbulkan oleh radiasi ultraviolet pada kulit adalah terjadinya kerusakan epidermis yang biasa disebut dengan sengatan surya, pigmentasi, pengerutan kulit ${ }^{[1]}$. Selain itu, sinar UV dari sinar matahari dapat menyebabkan sunburn, penuaan dini, bahkan kanker kulit. Secara normal kulit memiliki perlindungan alami terhadap paparan sinar matahari, namun hal tersebut tidak mencukupi dibandingkan 
dengan radiasi sinar UV yang ada sehingga dibutuhkan perlindungan buatan, salah satunya dengan penggunaan tabir surya ${ }^{[2]}$.

Selain tabir surya sintesik terdapat pula tabir surya alami di alam. Misalnya senyawa fenolik yang terdapat dalam tumbuhan dan berfungsi melindungi jaringan tanaman terhadap kerusakan akibat radiasi sinar matahari ${ }^{[3]}$. Kemampuan tabir surya dalam melindungi kulit dan mencegah paparan sinar matahari ditunjukkan oleh nilai SPF (Sun Protection Factor). Semakin tinggi nilai SPF suatu bahan tabir surya, maka semakin baik pula kemampuan perlindungannya ${ }^{[4]}$.

Salah satu tanaman yang berpotensi untuk dimanfaatkan sebagai bahan tabir surya adalah miana (Coleus atropurpureus Benth.). Daun miana mengandung saponin, flavonoida, polifenol, dan minyak atsiri ${ }^{[5]}$. Menurut penelitian Sari (2013) aktivitas antioksidan pada daun miana cukup tinggi dimana $\mathrm{IC}_{50}$ yang dimiliki pada ekstrak etanolnya yaitu 48,04 ppm, fraksi etil asetat yaitu $22,98 \mathrm{ppm}^{[6]}$. Selain itu, menurut penelitian Amrillah (2015) daun miana memiliki aktivitas tabir surya dilihat dari \% Te dan $\%$ Tp dimana ekstrak etanol pada konsentrasi $250 \mathrm{ppm}$ termasuk kategori suntan standar dan fraksi etil asetat pada konsentrasi 125 ppm termasuk kategori proteksi ekstra tetapi belum diteliti mengenai gambaran nilai SPF dari daun miana ${ }^{[7]}$.

Oleh karena itu dalam penelitian ini akan menguji nilai SPF dari ekstrak etil asetat daun miana dan menentukan kategori tabir surya ekstrak etil asetat daun miana secara in vitro dengan menggunakan Spektrofotometri UV-VIS.

\section{METODE PENELITIAN}

\section{Bahan}

Bahan yang digunakan dalam penelitian ini adalah daun miana, pelarut n-heksana, pelarut etil asetat, etanol pro analitik.

\section{Peralatan}

Peralatan yang digunakan dalam penelitian ini yaitu neraca analitik, rotary evaporator, waterbath, Spektrofotometer UV-VIS, seperangkat alat gelas laboratorium.

\section{Prosedur Penelitian}

\section{Pembuatan Ekstrak}

Sampel diekstraksi dengan metode maserasi bertingkat dimana sampel diekstraksi terlebih dahulu dengan pelarut n-heksana kemudian residu sampel diekstraksi kembali dengan menggunakan 1 liter pelarut etil asetat. Ekstrak cair yang didapatkan lalu diuapkan dengan rotary evaporator pada suhu $50{ }^{\circ} \mathrm{C}$ dan dipekatkan dengan waterbath hingga didapatkan ekstrak kental etil asetat daun miana.

\section{Penentuan nilai SPF}

Uji aktivitas tabir surya dilakukan dengan menentukan nilai SPF secara in vitro menggunakan spektrofotometri UV-Vis. Ekstrak etil asetat daun miana dilarutkan dengan pelarut etanol p.a sehingga diperoleh larutan dengan konsentrasi 1000 ppm kemudian diencerkan dengan etanol p.a hingga didapatkan konsentrasi $75 \mathrm{ppm}, 125 \mathrm{ppm}$ dan 250 ppm. Larutan ekstrak etil asetat daun miana tersebut dibaca absorbansinya pada panjang gelombang antara 290-320 nm tiap interval $5 \mathrm{~nm}$. 
Penentuan nilai SPF dilakukan berdasarkan Persamaan Mansur (1986) yaitu ${ }^{[8]}$ : $\mathrm{SPF}=\mathrm{CF} \times \sum_{290}^{320} \mathrm{EE} \times \mathrm{I} \times \mathrm{Abs}$

Keterangan :

$\mathrm{CF}=$ Faktor koreksi (10)

$\mathrm{EE}=$ Spektrum efek eritema

I $\quad=$ Spektrum intensitas cahaya

Abs $=$ Absorbansi sampel

Nilai EE $\times$ I merupakan nilai konstan yang telah ditetapkan, ditunjukkan pada tabel 1.

Tabel 1. Nilai EE $\times$ I

\begin{tabular}{cc}
\hline$\lambda(\mathrm{nm})$ & $\mathrm{EE} \times \mathrm{I}$ \\
\hline 290 & 0,015 \\
295 & 0,0817 \\
300 & 0,2874 \\
305 & 0,3278 \\
310 & 0,1864 \\
315 & 0,0839 \\
320 & 0,018 \\
\hline
\end{tabular}

\section{HASIL DAN PEMBAHASAN}

Ekstrak adalah sediaan kental yang diperoleh dengan mengekstraksi senyawa aktif dari simplisia menggunakan pelarut yang sesuai, kemudian semua atau hampir semua pelarut diuapkan. Metode ekstraksi yang digunakan adalah maserasi, proses penyarian simplisia menggunakan cairan penyari dengan perendaman dan beberapa kali pengadukan pada temperatur ruangan ${ }^{[9]}$. Proses maserasi sampel dimulai dari pelarut $n$-heksana untuk menarik senyawa-senyawa yang nonpolar kemudian sampel diekstraksi kembali dengan pelarut etil asetat. Menurut Amrillah (2015) fraksi etil asetat memiliki aktivitas tabir surya dengan kategori proteksi ekstra sehingga pada penelitian ini sampel diekstraksi dengan pelarut etil asetat. Etil asetat merupakan pelarut yang bersifat semi polar sehingga mampu menarik senyawa yang bersifat polar maupun nonpolar sehingga diharapkan senyawasenyawa yang polar seperti senyawa fenolik termasuk flavonoid dan antosianin dapat tersari.

Pengujian aktivitas tabir surya dilakukan untuk menentukan nilai SPF dengan mengukur absorbansi larutan ekstrak menggunakan spektrofotometer UV-Vis panjang gelombang antara 290-320 nm tiap interval $5 \mathrm{~nm}$, yakni panjang gelombang sinar UV-B yakni sinar UV yang dapat menyebabkan eritema pada kulit. Hasil absorbansi dapat dilihat pada tabel 2.

Hasil absorbansi yang didapatkan dari masing-masing konsentrasi ekstrak digunakan untuk menentukan nilai SPF berdasarkan persamaan Mansur (1986) sehingga diperoleh nilai SPF masing-masing konsentrasi ekstrak seperti yang terlihat pada tabel 3 .

Larutan ekstrak etil asetat daun miana dengan konsentrasi 75 ppm memiliki nilai SPF 4, konsentrasi 125 ppm memiliki nilai SPF 7 sedangkan konsentrasi 250 ppm memiliki nilai SPF 14. Menurut Wasitaatmadja (1997), nilai SPF 4 tergolong dalam tabir surya dengan kemampuan proteksi minimal, nilai SPF 7 tergolong dalam tabir surya kategori proteksi ekstra, nilai SPF 14 tergolong dalam kategori tabir surya dengan 
kemampuan proteksi maksimal ${ }^{[10]}$. Suatu tabir surya dikatakan dapat memberikan perlindungan bila memiliki nilai SPF minimal 2 dan kategori penilaian tabir surya yang baik apabila sampel uji memiliki nilai SPF di atas 15 .

Tabel 2. Hasil Absorbansi Larutan Ekstrak Etil Asetat Daun Miana

\begin{tabular}{cccc}
\hline \multirow{2}{*}{$\lambda(\mathrm{nm})$} & \multicolumn{3}{c}{ Absorbansi } \\
\cline { 2 - 4 } & $75 \mathrm{ppm}$ & $125 \mathrm{ppm}$ & $250 \mathrm{ppm}$ \\
\hline 290 & 0,479 & 0,781 & 1,585 \\
295 & 0,447 & 0,728 & 1,470 \\
300 & 0,425 & 0,693 & 1,397 \\
305 & 0,417 & 0,680 & 1,373 \\
310 & 0,412 & 0,686 & 1,390 \\
315 & 0,437 & 0,712 & 1,445 \\
320 & 0,452 & 0,735 & 1,492 \\
\hline
\end{tabular}

Tabel 3. Hasil Penentuan Nilai SPF

\begin{tabular}{|c|c|c|c|c|}
\hline \multirow{2}{*}{$\lambda(\mathrm{nm})$} & \multirow{2}{*}{$\mathrm{EE} \times \mathrm{I}$} & \multicolumn{3}{|c|}{$\mathrm{EE} \times \mathrm{I} \times \mathrm{Abs}$} \\
\hline & & $75 \mathrm{ppm}$ & $125 \mathrm{ppm}$ & $250 \mathrm{ppm}$ \\
\hline 290 & 0.015 & 0,0071 & 0,0117 & 0,0237 \\
\hline 295 & 0.0817 & 0,0365 & 0,0594 & 0,1200 \\
\hline 300 & 0,2874 & 0,1221 & 0,1991 & 0,4014 \\
\hline 305 & 0,3278 & 0,1366 & 0,2229 & 0,4500 \\
\hline 310 & 0,1864 & 0,0767 & 0,1278 & 0,2590 \\
\hline 315 & 0,0839 & 0,0366 & 0,0597 & 0,1212 \\
\hline 320 & 0,018 & 0,0081 & 0,0132 & 0,0268 \\
\hline \multicolumn{2}{|c|}{ Total } & 0,4237 & 0,6938 & 1,4021 \\
\hline
\end{tabular}

Potensi sebagai tabir surya yang dimiliki oleh daun miana dikarenakan terdapat kandungan senyawa fenolik khususnya golongan flavonoid yang terdapat dalam tumbuhan dan berfungsi melindungi jaringan tanaman terhadap kerusakan akibat radiasi sinar matahari. Hal ini karena flavonoid mempunyai gugus kromofor (ikatan rangkap tunggal terkonjugasi) yang mampu menyerap sinar UV baik UV A maupun UV B sehingga mengurangi intensitasnya pada kulit. Senyawa fenolik seperti flavonoid dapat berperan sebagai tabir surya untuk mencegah efek yang merugikan akibat radiasi UV pada kulit karena aktivitas antioksidan yang bersifat sebagai fotoprotektif.

Kemampuan tabir surya ekstrak etil asetat daun miana dipengaruhi oleh konsentrasi ekstrak. Hal ini ditunjukkan adanya peningkatan absorbansi seiring dengan meningkatnya konsentrasi ekstrak sehingga semakin besar konsentrasi larutan ekstrak maka semakin besar pula nilai SPF dan kemampuannya sebagai tabir surya.

\section{KESIMPULAN}

Berdasarkan penentuan nilai SPF ekstrak etil asetat daun miana memiliki kemampuan sebagai tabir surya pada konsentrasi 75 ppm dengan nilai SPF 4, konsentrasi 125 ppm dengan nilai SPF 7, konsentrasi 250 ppm dengan nilai SPF 14. Nilai SPF 4 menunjukkan tingkat kemampuan tabir surya minimal, nilai SPF 7 menunjukkan tingkat 
kemampuan tabir surya ekstra dan nilai SPF 14 menunjukkan tingkat kemampuan tabir surya dalam kategori maksimal.

\section{DAFTAR PUSTAKA}

1. Agustin, Rini dkk. 2013. Formulasi krim Tabir Surya dari Kombinasi Etil p Metoksisinamat dengan Katekin. Prosiding Seminar Nasional Perkembangan Terkini Sains Farmasi dan Klinik III. 184-198

2. Wang, S.Q., Stanfield, M.S., Osterwalder, U. 2008. In Vitro Assessment of UV A Protection by Populer Sunscreen Available in the United States. Journal American Dermatology. 59. 934-942

3. Shovyana, Hidayatu Hana And Zulkarnain, A. Karim. 2013. Physical Stability And Activity Of Cream W/O Etanolic Fruit Extract Of Mahkota Dewa (Phaleria Macrocarpha (Scheff.) Boerl,) As A Sunscreen. Traditional Medicine Journal. 18. (2). 109-117

4. Rahmawanty, Dina \& Fadhillaturrahmah. 2014. Studi Aktivitas Tabir Surya Buah Limpasu (Baccaurea Lanceolata) Berdasarkan Penentuan Nilai Sun Protection Factor (SPF) Secara In Vitro. Jurnal Pharmascience. 1. (1). 55-58

5. Hutapea, Johnny Ria. 2000. Inventaris Tanaman Obat Indonesia (I) Jilid 1. Depkes RI. Jakarta.

6. Sari, Devi Dewinta. 2013. Uji aktivitas Antioksidan Ekstrak Daun Miana (Coleus Atropurpuresus L. Benth.) terhadap DPPH (1,1-Diphenyl-2-Picrylhidrazyl. Universitas Mulawarman: Samarinda.

7. Amrillah, M.S., Rusli, R., Fadraersada, J., 2015. Aktivitas Tabir Surya Daun Miana (Coleus atropurpureus L. Benth) Secara In Vitro. Jurnal Sains Dan Kesehatan, 1(4), 168-174. DOI: https://doi.org/10.25026/jsk.v1i4.35

8. Mansur, J.S., Breeder, M.N., Azulay, R.D. 1986. Determinação do fator de proteção solar por espectrofotometria, An. Bras. Dermatol. 61. 121-24.

9. Ditjen POM. 2000. Parameter Standar Umum Ekstrak Tumbuhan Obat. Departemen Kesehatan Republik Indonesia. Jakarta.

10. Wasitaatmadja, S. M. 1997. Penuntun Ilmu Kosmetik Medik. UI-Press. Jakarta. 